\title{
Expression of HBsAg and HBcAg in Liver Biopsy Specimens of Chronic B Hepatitis Patients and its Relation with Histology Activity Index
}

\author{
Budiana Tanurahardja, Esti Soetrisno B, Sutjahjo Endardjo, Gunawan Tjahjadi, Wirasmi Marwoto
}

\begin{abstract}
Abstrak
Mempelajari hubungan antara Indeks Aktivitas Histologik (LAH) dengan ekspresi HBsAg dan HBcAg. Diteliti 30 sediaan biopsi hati penderita hepatitis B kronik. Ekspresi HBsAg dan HBcAg ditentukan berdasarkan pulasan imunoperoksidase yang dilakukan pada semua sediaan yang positif pada pulasan Victoria Blue (VB), sedangkan LAH ditentukan berdasarkan metode Knodell. Semua sediaan (29 buah) menunjukkan HBsAg dan HBcAg positif. Pola sebaran HBsAg yang 'regular uniform' terdapat pada 3 sediaan dan 'irregular dan non-uniform' pada 26 sediaan. Pola sebaran HBcAg yang 'regular-uniform' terdapat pada 4 sediaan, sedangkan pola 'irregular non-uniform' terdapat pada 25 sediaan. HBsAg 1+ pada semua sediaan dengan IAH=1-18. HBcAg pada sitoplasma/membran sel $1+$ pada 20 sediaan, $2+$ pada 3 sediaan, dan 3+ pada 6 sediaan. Nilai IAH pada masing-masing kelompok ini tidak berbeda bermakna. HBCAg pada inti sel 1+ pada 14 sediaan, dan (-) pada 15 sediaan. Nilai LAH pada masing-masing kelompok ini tidak berbeda bermakna. Nilai IAH pada kelompok dengan pola sebaran HBsAg dan HBCAg yang 'regular-uniform' tidak berbeda bermakna dengan kelompok dengan pola sebaran yang 'irregular non-uniform'. Ekspresi HBsAg dan HBcAg pada sediaan biopsi hati penderita hepatitis B kronik pada penelitian ini tidak berhubungan dengan aktivitas nekroinflamasi.
\end{abstract}

\begin{abstract}
To assess the relationship between Histology Activitiy Index (HAI) and the expression of HBsAg and HBcAg. Thirty liver biopsy specimens of chronic $B$ hepatitis patients have been examined. Expression of HBsAg and HBcAg were determined by immunoperoxidase staining. HAI was calculated according to Knodell's method. All of the specimens (29) were positive for HBsAg and HBcAg staining. Regular-uniform distribution patterns of HBsAg were found in 3 specimens and irregular non-uniform patterns in 26 specimens . Regular-uniform patterns of HBCAg were found in 4 specimens and the irregular non-uniform patterns in 25 specimens. HBsAgs $1+$ were seen in all specimens which have HAI range of 1 to 18. Cytoplasmic/membraneous HBcAgs were seen $1+$ in 20 specimens, $2+$ in 3 specimens, and $3+$ in 6 specimens. HAI of each group which showed HBcAg was not significantly different. HBcAgs in the nuclei of liver cells were seen $1+$ in 14 specimens, and 15 specimens were negative. HAI of each of these groups showed no significant differences. HAI of regular-uniform distribution pattern groups of $\mathrm{HBSAg}$ and $\mathrm{HBCAg}$ were not significantly different from HAI of irregular non-uniform groups. Expression of HBsAg and HBcAg in liver biopsy specimens. of chronic B hepatitis patients are not correlated with necroinflammatory activity.
\end{abstract}

Key words: Expression of HBsAg and HBcAg - necroinflammatory activity - histology activity index.

Viral hepatitis B infection is one of the major world health problems. There are about three hundred millions carriers of $\mathrm{HBV}$ in the world, and seventy-eight

Department of Anatomic Pathology, Faculty of Medicine University of Indonesia/Dr. Cipto Mangunkusumo National Central General Hospital, Jakarta, Indonesia percents are found in Asia. ${ }^{1}$ According to the World Health Organization (WHO), Indonesia is an endemic country, with moderate (2\%-7\%) to high (7\%-20\%) prevalence of $B$ hepatitis. The incidence of $\mathrm{HBV}$ infection was varied in each region.

According to the Fogarty International Center Criteria Committee (1976), chronic hepatitis was defined as inflammation of the liver which continues without 
improvement more than six months. The liver cirrhosis is defined as a diffuse process characterized by fibrosis and conversion from normal architecture of liver cells to abnormal structure of noduli. ${ }^{2,3,4,5}$

Due to the rapid progression of medical sciences and technology especially the discovery of new hepatitis viruses which showed characteristic features of liver changes as well as new therapeutical modulations such as interferon, a new classification of diagnosis of liver biopsies which specifically express the etiology, grading and staging of the chronic liver disease is needed. ${ }^{6,7,8,9,10}$ It is understood that liver biopsy is not a gold standard for etiological diagnosis, as clinical and serological features do. ${ }^{11}$ But liver biopsy still has a good role in supporting and monitoring the tissue activity reaction.

For grading of the disease most authors suggest to use Knodell's Histology Activity Index (HAI) ${ }^{12}$ because of its objectivity and reproducibility. Furthermore it gives more detailed information about necroinflammatory activity, although several authors critisized the use of HAI on the admixture of grading and staging of the disease. ${ }^{6,8,9,10}$ Liver cirrhosis, according to the new classification, is an advanced stage of chronic hepatitis.

Necroinflammatory activity is often associated with the expression of the antigen, thus give information about the existence of viral life cycle in liver cells. Suzuki et al $^{13}$ reported that necroinflammatory activity in Chronic Persistent Hepatitis ( $\mathrm{CPH})$ is always parallel with viral replication, but not in Chronic Active Hepatitis (CAH). Suzuki evaluated and described the expression of $\mathrm{HBsAg}$ and $\mathrm{HBcAg}$ intracellularly, intralobularly and interlobularly. It is quite practical that the Suzuki's way was used in this study.

The aims of this study were to learn expression of $\mathrm{HBs} \mathrm{Ag}$ and $\mathrm{HBcAg}$ in liver biopsy specimens and its relation with necroinflammatory activity, as well as to determine grading of the disease using Knodell's HAI as a parameter of necroinflammatory activity.

\section{METHODS}

Materials were taken from the archives of Department of Anatomic Pathology, Faculty of Medicine, University of Indonesia, Dr.Cipto Mangunkusumo National Central General Hospital, Jakarta received in 1992.

These materials were liver biopsy specimens (open biopsy or/ needle biopsy) of chronic B hepatitis patients which were positive with Victoria Blue (VB) staining. We had 116 specimens of chronic hepatitis and liver cirrhosis, 43 of them were positive to VB staining. The number of the paraffin blocks which were still available and could be recut were 30 .

Based on three routine stainings (Hematoxylin \& Eosine, van Gieson and reticulin), histopathological diagnoses were made and Knodell's HAI criteria was applied on each slide. Diagnosis was based on the modified International Group Classification of Chronic Liver Disease 1977. 14,15

1. Chronic Persistent Hepatitis (CPH)

2. Chronic Active Hepatitis (CAH):

a. with moderate activity (IIa)

b. with severe activity (IIb)

3. Liver cirrhosis (LC) :

a. CAH IIb with early cirrhosis

b. liver cirrhosis

Knodell's HAI was determined according to four components:

I. Periportal necrosis, score 0 - 10.

II. Focal necrosis and intralobular degeneration, score 0 - 4.

III. Portal inflammation, score 0 - 4 .

IV. Fibrosis, score 0 - 4 .

The sum of the score from each component was taken as HAI ranging from 0 to 22 .

Immunoperoxidase stainings were made on each specimen. The Peroxidase Anti-Peroxidase (PAP) method was used for $\mathrm{HBsAg}$ and the Avidin-Biotin Complex (ABC) method for $\mathrm{HBcAg}$. For $\mathrm{HBsAg}$, goat anti-HBsAg was used as primary antibody, and peroxidase- conjugated rabbit anti-goat immunoglobulins as linking antibody. For $\mathrm{HBcAg}$, rabbit anti-HBcAg was used as primary antibody and biotinylated goat anti-rabbit immunoglobulins as linking antibody. All antibodies used were from Dakopatts.

After staining by the immunoperoxidase method each specimen was evaluated by the method of Suzuki:

- intracellular : intranucleus, intracytoplasmic and membraneous.

- intralobular/intranodular : regular, irregular interlobular : uniform, non-uniform.

The number of positive liver cells in each specimen is classified semiquantitatively :

$1+=1-25 \%$ positive

$2+\quad=26-50 \%$ positive

$3+=51-75 \%$ positive

$4+\quad=76-100 \%$ positive 
The quality of immunoperoxidase staining was controlled by providing the slides for positive and negative control.

Microscopic examination was done using Olympus binocular light microscope.

\section{Statistical analysis:}

Non-parametric statistics were used as appropriate :

$-\mathrm{X}^{2}$ test

- Kruskal-Wallis test

- Wilcoxon rank sum test

- Spearman's rank correlation test

\section{RESULTS}

The age of patients ranged from 21 years to 59 years. Sex ratio ( male to female) was $4: 1$. (Table 1 and 2 )

Table 1. Age distribution of the cases

\begin{tabular}{ccccccc}
\hline Age(yr) & CPH & CAHIla & CAHIIb & CAH+EC & LC & Total \\
\hline $20-29$ & 4 & 0 & 2 & 0 & 0 & 6 \\
$30-39$ & 2 & 0 & 2 & 2 & 2 & 8 \\
$40-49$ & 1 & 1 & 1 & 0 & 2 & 5 \\
$50-59$ & 1 & 0 & 1 & 1 & 0 & 3 \\
$\begin{array}{c}\text { not } \\
\text { mentioned }\end{array}$ & & & & & & 8 \\
\hline
\end{tabular}

Table 2. Sex distribution of the cases

\begin{tabular}{lccc}
\hline Diagnosis & Male & Female & Total \\
\hline CPH & 6 & 2 & 8 \\
CAH IIa & 1 & 1 & 2 \\
CAH IIb & 10 & 2 & 12 \\
CAH+EC & 3 & 0 & 3 \\
LC & 4 & 1 & 5 \\
\hline & $24(80 \%)$ & $6(20 \%)$ & 30 \\
\hline
\end{tabular}

Immunoperoxidase staining for $\mathrm{HBsAg}$ and $\mathrm{HBcAg}$ were positive in 29 cases. One case had a nonspecific reaction and was dropped out from this study. Distribution patterns of $\mathrm{HBsAg}$ and $\mathrm{HBcAg}$ were evaluated by Suzuki's method and compared with standard histopathological diagnosis.

CAH IIa (2 specimens) and CAH IIb (12 specimens) were grouped as $\mathrm{CAH}$ group. $\mathrm{CAH}$ with early cirrhosis ( 3 specimens) were classified as LC group. There is no significant association between the distribution pattern of $\mathrm{HBsAg}$ as well as that of $\mathrm{HBcAg}$ and the histopathological diagnosis.(Table 3)

Table 4 shows a significant correlation ( $p<0,001)$ between Knodell's HAI and histopathological diagnosis.

Table 3. HBsAg and $\mathrm{HBcAg}$ distribution patterns of liver biopsy specimens

\begin{tabular}{lccrrrr}
\hline Diagnosis & $\begin{array}{c}\text { Reg,uni } \\
\text { HBsAg HBcAg }\end{array}$ & \multicolumn{2}{c}{ Ir,non } & \multicolumn{2}{c}{ Total } \\
& HBsAg HBcAg & HBsAg & HBcAg \\
\hline CPH & 2 & 1 & 5 & 6 & 7 & 7 \\
CAH & 0 & 3 & 14 & 11 & 14 & 14 \\
LC & 1 & 0 & 7 & 8 & 8 & 8 \\
\hline & 3 & 4 & 26 & 25 & 29 & 29 \\
\hline
\end{tabular}

Table 4. Association Between Knodell's HAI and histopathological diagnosis

\begin{tabular}{|c|c|c|c|c|}
\hline \multirow{2}{*}{ Diagnosis } & \multirow{2}{*}{ Total } & \multirow[t]{2}{*}{ HAI } & \multirow[b]{2}{*}{$\bar{x}$} & \multirow[b]{2}{*}{ SD } \\
\hline & & & & \\
\hline $\mathrm{CPH}$ & 8 & $1,3,3,3,4,4,5,7$ & 3,75 & 1,7 \\
\hline CAH & 14 & $\begin{array}{l}7,10,10,11,12,12,12 \\
12,12,12,14,14,15,16\end{array}$ & 12,07 & 2,2 \\
\hline LC & 8 & $11,12,13,13,14,15,16,18$ & 14 & 2,2 \\
\hline
\end{tabular}

If the fourth component of Knodell's HAI (i.e. fibrosis) is removed, a significant relationship between HAI and histopathological diagnosis is still observed. (Table 5)

Table 5. Association between HAI without the fourth component (fibrosis) and histopathological diagnosis

\begin{tabular}{|c|c|c|c|c|}
\hline \multirow{2}{*}{ Diagnosis } & \multirow{2}{*}{ Total } & \multirow[t]{2}{*}{ HAI -IV } & \multirow[b]{2}{*}{$\bar{x}$} & \multirow[b]{2}{*}{$\mathrm{SD}$} \\
\hline & & & & \\
\hline $\mathrm{CPH}$ & 8 & $1,2,3,3,3,3,5,7$ & 3,37 & 1,8 \\
\hline CAH & 14 & $\begin{array}{l}7,7,7,9,9,9,9,9,9 \\
10,11,11,11,13\end{array}$ & 9,3 & 1,7 \\
\hline LC & 8 & $7,9,9,9,10,11,13,14$ & 10,25 & 2,3 \\
\hline
\end{tabular}

In order to know whether necrosis was always accompanied by inflammation in the histopathological specimens of chronic B hepatitis patients; we correlated the first (periportal necrosis) and second (focal necrosis) component of HAI to the third one (portal inflammation). A significant correlation $\left(r_{s}=0,64\right.$, $\mathrm{p}<0,001$ ) was observed. (Figure 1) 


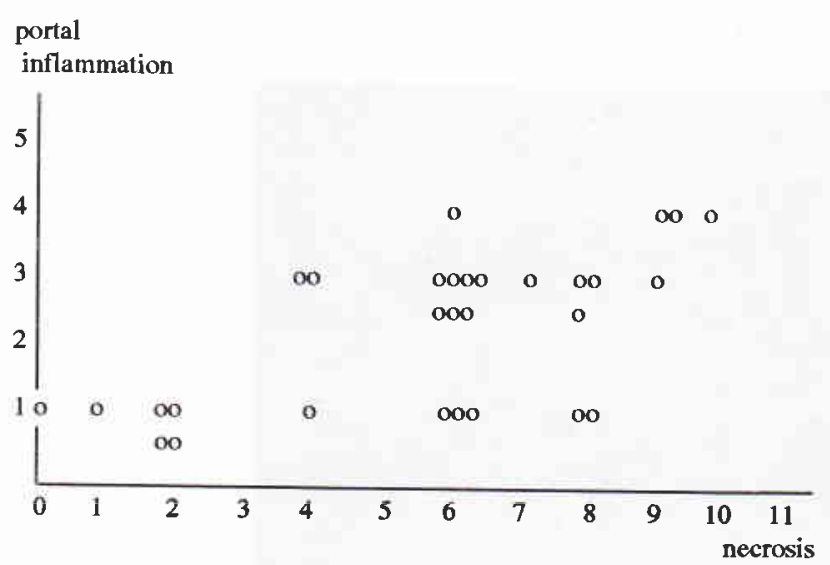

Figure 1. Scattered diagram of necrotic component and portal inflammation component of $H A I$.

All specimens (29) were positive $1+$ for $\mathrm{HBsAg}$ expression in the cytoplasm of the liver cells, whereas for $\mathrm{HBcAg}$ expression, 29 specimens were positive in the cytoplasm ( 20 specimens $1+, 3$ specimens $2+$ and 6 specimens $3+$ ) and 14 specimens in the nuclei. For $\mathrm{HBcAg}$ in the nuclei of liver cells 14 specimens showed $1+$, the others were negative.(Table 6 )

Tabel 6. HAI of the groups of positive $\mathrm{HBcAg}$ expression in cytoplasm/cell membrane and in the nuclei of liver cells

\begin{tabular}{|c|c|c|c|}
\hline \multicolumn{2}{|c|}{ HBcAg express. } & \multirow[t]{2}{*}{ HAI } & \multirow{2}{*}{$\frac{\text { Total }}{0}$} \\
\hline \multirow{2}{*}{ - } & $\mathrm{CC}$ & & \\
\hline & $\mathrm{N}$ & $\begin{array}{l}15,15,14,14,13,12,12,12,11,10,7,4 \\
4,3,3\end{array}$ & 15 \\
\hline \multirow{2}{*}{+} & $\mathrm{CC}$ & $\begin{array}{l}15,15,14,14,13,13,12,12,12,12,11 \\
10,7,7,5,4,4,3,3,1\end{array}$ & 20 \\
\hline & $\mathrm{N}$ & $\begin{array}{l}18,16,16,14,13,12,12,12,12,11,10 \\
7,5,1\end{array}$ & 14 \\
\hline \multirow{2}{*}{++} & $\mathrm{CC}$ & $16,16,11$ & 3 \\
\hline & $\mathrm{N}$ & & 0 \\
\hline \multirow{2}{*}{+++} & $\mathrm{CC}$ & $18,14,12,12,12,10$ & 6 \\
\hline & $\mathrm{N}$ & & 0 \\
\hline
\end{tabular}

Note: $\mathrm{CC}=$ cytoplasm/ cell membrane

$\mathbf{N}=$ nuclei

There were no association between $\mathrm{HAI}$ and the number of $\mathrm{HBcAg}$ positive cells in cytoplasm $(\mathrm{p}>0,05)$ as well as $\mathrm{HBcAg}$ positive in the nuclei.
Three specimens showed regular-uniform patterns of HBsAg expression with Histology Activity Index of 3, 5 , and 18 respectively. These scores did not show any significant differences ( Wilcoxon rank sum test, $\mathrm{p}>$ 0,05 ), with HAI of group showing irregular- non uniform pattern, so the expression pattern of $\mathrm{HBsAg}$ in liver tissue did not have any relationship with HAI (table 7).

Table 7. HAI of the regular-uniform pattern and irregular non uniform pattern of HBsAg AND HBcAg expression

\begin{tabular}{|c|c|c|c|}
\hline Pattem & & HAI & Total \\
\hline \multirow{2}{*}{ REG - UNI } & HBsAg & $3,5,18$ & 3 \\
\hline & $\mathrm{HBcAg}$ & $7,12,12,14$ & 4 \\
\hline \multirow{2}{*}{ IR - NON } & HBsAg & $\begin{array}{l}1,3,4,4,7,7,10,10,11,11,12,12,12,12 \\
12,12,12,13,13,14,14,14,15,15,16,16\end{array}$ & 26 \\
\hline & $\mathrm{HBcAg}$ & $\begin{array}{l}1,3,3,4,4,5,7,10,10,11,11,12,12,12 \\
12,12,13,13,14,14,15,15,16,16,18\end{array}$ & 25 \\
\hline
\end{tabular}

Four specimens which showed regular-uniform patterns of $\mathrm{HBcAg}$ expression also did not show any significant differences (Wilcoxon rank sum test, $\mathrm{p}>$ 0,05 ) compared with HAI of the group of specimens with irregular-non uniform patterns. Here again the expression pattern of $\mathrm{HBcAg}$ did not have an association with $\mathrm{HAI}$.

\section{DISCUSSION}

In this study, the chronic B hepatitis were mostly encountered in the age group of $30-39$ years, with a male to female sex ratio of $4: 1$. This is in agreement with Sherlock's report ${ }^{4}$ that chronic B hepatitis infections could be encountered at any age groups and especially in males. Several authors ${ }^{4,16}$ said that the earlier the onset of the disease (in neonatal / perinatal period), the greater the possibility of becoming chronic and cirrhosis.

$\mathrm{HBsAg}$ and $\mathrm{HBcAg}$ liver tissue expression in $\mathrm{CAH}$ and LC most frequently showed an irregular-non uniform feature as reported by Suzuki. ${ }^{13}$ In this study, however, $\mathrm{CPH}$ also showed an irregular- non uniform feature as has been in CAH and LC, not similar to Suzuki's findings. According to Suzuki, in $\mathrm{CPH}$ and healthy carriers the features of $\mathrm{HBsAg}$ and $\mathrm{HBcAg}$ expression in liver tissue were uniform among the lobules. Suzuki also found irregular expression patterns of $\mathrm{HBsAg}$ in 


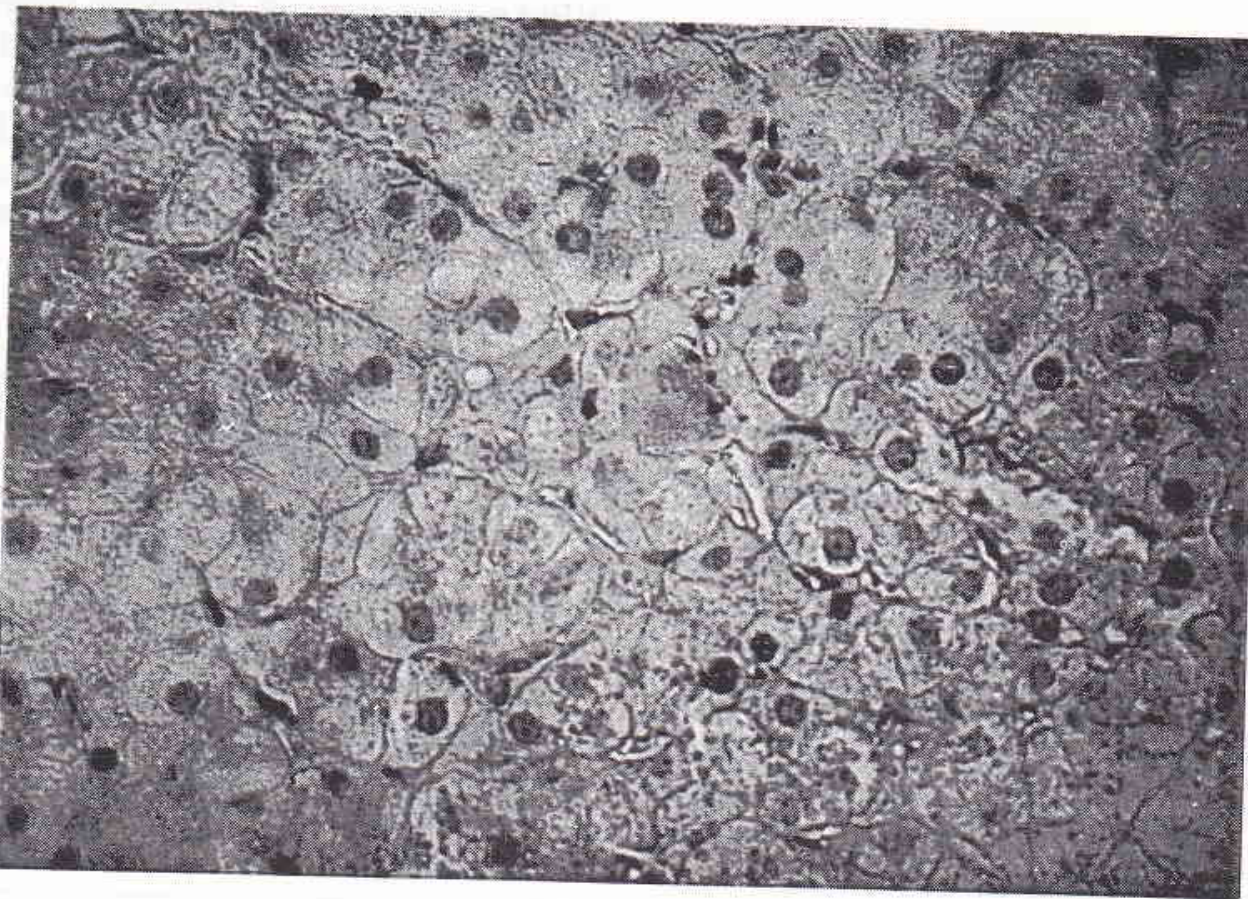

Figure 2. Expression of HBsAg in the cytoplasma of liver cell from cirrhotic patient (PAP, 528X)

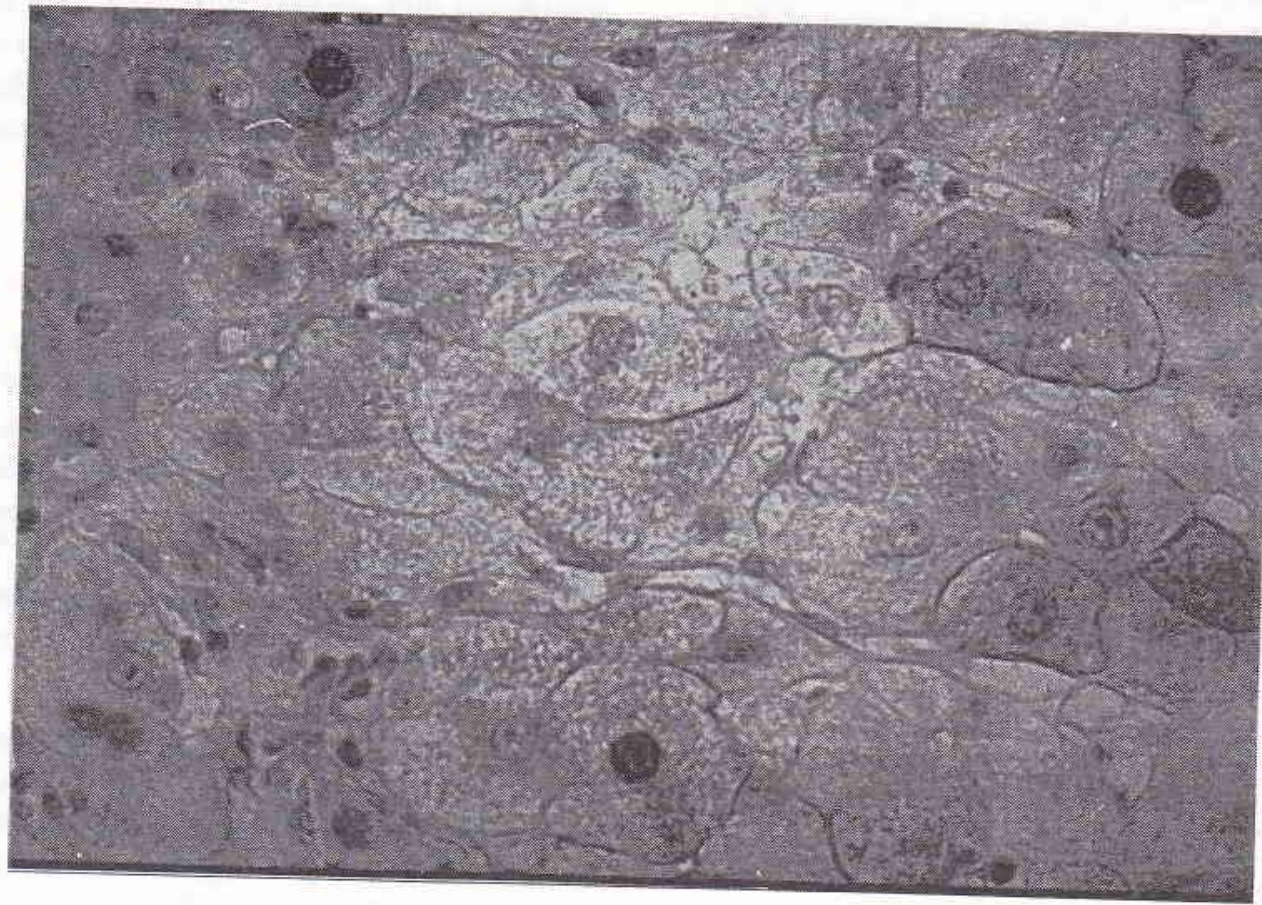

Figure 3. Expression of HBCAg in the nuclei, cytoplasm and cell membrane of liver cells in LC patient (ABC, $528 X)$ 
CPH patients who had seroconversion to positive anti$\mathrm{HBe}$. The HBcAg expression in these cases were negative. It is not known whether the cases in this study have anti-HBe in their sera, since the clinical data were incomplete. $\mathrm{HBsAg}$ expression in $\mathrm{CPH}$ in this study were found in one or two liver cells and Kupffer cells, which was similar to the solitary pattern reported by Akeyama et al ${ }^{17}$ in mild hepatitis. Ten Kate ${ }^{18}$ found that same expression is frequently seen in acute hepatitis. The basic pathological process of $\mathrm{CPH}$ was different from that of $\mathrm{CAH}{ }^{13}$. In $\mathrm{CPH}$ patients with positive $\mathrm{HBeAg}$ and in the healthy carriers, the immunologic response was inadequate or totally deficit so that the virus replicate freely. Chu and Liaw 19 called it as high replicative immunetolerance phase. In $\mathrm{CAH}$, the patient's immunologic response suppress and destroy viral replication irregularly. Irregular immunological response and regeneration of liver cells, as well as integration of HBV-DNA in liver cells, caused $\mathrm{HBsAg}$ and $\mathrm{HBcAg}$ expression patterns to become irregular-non uniform. Chu and Liaw called it as low replicative immune clearance phase. In $\mathrm{CPH}$ with seroconversion to positive anti-HBe, patient's immunologic response increased and caused distortion of viral replication, so that the patterns became irregular. This phase is called non-replicative recidual integration phase. ${ }^{19}$

Application of Knodell's HAI on histopathological specimens, showed that HAI in the group of $\mathrm{CPH}$, CAH and LC differed significantly. Knodell's results were that the HAI tend to be low in mild chronic hepatitis $(\mathrm{CPH})$ and high in severe chronic hepatitis (CAH and LC). ${ }^{13}$ In this study we tried to compare the histopathological diagnosis and HAI without the fourth component. The results showed that this was similar with previous results using complete HAI. It meant that to determine histological activity we could use either 3 or 4 components of HAI.

The key feature to determine piecemeal necrosis or focal necrosis was infiltration of mononuclear inflammatory cells in that region. Instead of piecemeal necrosis and focal necrosis one used the term: necroinflammatory activity which was usually applied in chronic hepatitis, because necrosis was almost always accompanied by inflammatory reaction. In this study we tried to correlate the first and second component (periportal and focal necrosis) of HAI with the third component (portal inflammation). The results show a positive correlation. It meant that in chronic B hepatitis, necrosis is almost always accompanied by inflammation.

All specimens stained by HBsAg immunoperoxidase staining showed positive results in the cytoplasm of the liver cells, and negative in the cell membrane and the nuclei. The expression of HBsAg were not correlated with necroinflammatory activity featured by HAI as see by semiquantitative score. Besides, the regularuniform expression of $\mathrm{HBsAg}$ in the liver tissues were obtained in only 3 cases. The other twenty-six (26) cases showed irregular- non uniform pattern. HAI of the two groups showed no differences statistically, which meant that the distribution patterns of $\mathrm{HBsAg}$ and the number of $\mathrm{HBsAg}$ positive liver cells were not correlated with necroinflammatory activity.

All specimens stained by $\mathrm{HBcAg}$ immunoperoxidase staining were positive in the cytoplasm and cell membrane. Semiquantitatively the positive liver cells were $1+$ in 20 cases $(69 \%), 2+$ in 3 cases $(10 \%)$, and $3+$ in 6 cases $(21 \%)$. HAI from each groups were not statistically different. HBcAg expression in the nuclei of liver cells were found in 14 cases ( $48 \%$ ), with semiquantitative result of $1+$. There were no significant difference between $\mathrm{HAI}$ in the positive group and the negative group. Regular-uniform patterns of $\mathrm{HBcAg}$ expression were found in 4 cases, the other 25 cases showed irregular-non uniform patterns. There were no significant differences between these two groups in their HAI. So, HBcAg expression in liver tissue was not correlated with necroinflammatory activity.

The absence of correlation was also found between $\mathrm{HBsAg}$ expression and necroinflammatory activity. The same results had been reported by Chu and Liaw. 99 The work of Ray ${ }^{20}$ however, showed contrary results. $\mathrm{HBcAg}$ expression in this study was not correlated with necroinflammatory activity, and this was not in agreement with the results of many authors such as Chu and Liaw ${ }^{19}$, Ray ${ }^{20}$, Suzuki et al ${ }^{13}$, Yoo ${ }^{21}$ and the others. Other studies are needed to clarify this discrepancy.

We concluded that HBsAg expression in liver tissues had no association with necroinflammatory activity in the liver tissues. The absence of this association was also found for $\mathrm{HBcAg}$. Whether necroinflammatory activity also depend on other factors, such as host immune responses, need to be analyzed in further studies. The possibility that CD8 T lymphocytes had its role in this process, should also be envisaged.

\section{REFERENCES}

1. Bianchi L, Spichtin HP, Gudat F. Chronic hepatitis. In: Mac Sween RNM, Anthony PP, Scheuer PJ, eds. Pathology of the liver. New York: Churchill Livingstone, 1987:310-41. 
2. Millward-Sadler GH. Cirrhosis. In: MacSween RNM, Anthony PP, Scheuer PJ. eds. Pathology of the liver. Edinburg: Churchill Livingstone; 1987: 342-63.

3. Millward-Sadler GH, Hahn EG, Wright R. Cirrhosis : An appraisal. In: Wright $\mathrm{R}$, Millward-Sadler $\mathrm{GH}$, Alberti KGMM, Kiran S. eds. Liver and biliary disease. Pathophysiology, diagnosis, management. London: Bailliere Tindall Saunders ; 1985: 821-60.

4. Sherlock S, Dooley J, eds. Diseases of the liver and biliary system. Oxford : Blackwell Scientific Publications, 1993: 293- 313, 357-369.

5. Anthony PP, Ishak KG, Nayak NC, Poulsen HE, Scheuer PJ, Sobin LH. The morphology of cirrhosis. Recommendations on definition, nomenclature, and classification by a working group sponsored by the World Health Organization. J Clin Pathol 1978;31:395-414

6. Scheuer PJ. Classification of chronic viral hepatitis: a need for reassessment. J Hepatol 1991;13:372-4.

7. Czaja AJ. Chronic active hepatitis : the challenge for a new nomenclature. Ann Intern Med 1993;119:510-7

8. Ludwig J. The nomenclature of chronic active hepatitis : an obituary. Gastroenterology 1993;105:274-8.

9. Desmet VJ, Gerber M, Hoofnagle JH, Manns M, Scheuer PJ. Classification of chronic hepatitis: diagnosis, grading and staging. Hepatology 1994;19:1513-20.

10. Ishak KG. Chronic hepatitis : morphology and nomenclature. Modern Pathology 1994; 7:690-713.

11. Czaja AJ, Carpenter HA. Diagnostic standard for chronic hepatitis. Gastroenterology 1994;106:1723-27.

12. Knodell RG, Ishak KG, Black WC, Chen TS, Craig R, Kaplowitz N, et al. Formulation and application of numerical scoring system for assesing histological activity in asymptomatic chronic active hepatitis. Hepatology 1981;5:431-5.

13. Suzuki K, Uchida T, Shikata T. Histopathological analysis of chronic hepatitis B virus(HBV) infection in relation to HBV replication. Liver 1987: 260-70.

14. International Group. Acute and chronic hepatitis revisited. Lancet 1977;11:914-9.

15. De Groote J, Desmet VJ, Gedigk P, Korb G, Popper H, Poulsen $\mathbf{H}$ et al. A classification of chronic hepatitis. Lancet 1968;11:626-8.

16. Hsu HC, Lin YH, Chang MH, Su IJ, Chen DS. Pathology of chronic hepatitis $\mathrm{B}$ virus infection in children: with special reference to the intrahepatic expression of hepatitis $B$ virus antigens. Hepatology 1988;8:378-82.

17. Akeyama T, Kamada T, Koyama M, Abe H. Distribution patterns of hepatitis B antigen in the liver. Arch Pathol 1974; 98:252-6.

18. Ten Kate FJW. Hepatitis B. A light microscopical and immuno histochemical study ( Dissertation). Rotterdam, Netherland University of Rotterdam, 1989.281p

19. Chu CH, Liaw YF . Intrahepatic distribution of hepatitis $B$ surface and core antigens in chronic hepatitis $\mathrm{B}$ virus infection. Gastroenterology 1987: 220-5.

20. Ray MB, Desmet VJ, Bradburne AF, Desmyter J, Fevery J, De Groote J. Differential distribution of hepatitis B surface antigen and hepatitis $B$ core antigen in the liver of hepatitis B patients. Gastroenterology 1976; 71:462-7.

21. Yoo JY, Howard R, Waggoner JG, Hoofnagle JH. Hepatitis $\mathrm{B}$ core antigen in the cytoplasma and nuclei of hepatocytes from liver biopsies of patients with chronic type B hepatitis [Abstract]. Hepatology 1985;5:1033. 